\title{
Cold-Resistant Heterotrophic Ammonium and Nitrite-Removing Bacteria Improve Aquaculture Conditions of Rainbow Trout (Oncorhynchus mykiss)
}

\author{
Alireza Neissi $^{1} \cdot$ Gholamreza Rafiee $^{1} \cdot$ Hamid Farahmand $^{1} \cdot$ Shadi Rahimi $^{2} \cdot$ Ivan Mijakovic $^{2,3}$ (D)
}

Received: 1 December 2019 / Accepted: 19 February 2020 / Published online: 11 March 2020

(C) The Author(s) 2020

\begin{abstract}
The aim of this study was isolation and characterization of heterotrophic bacteria capable of ammonium and nitrite removal at $15{ }^{\circ} \mathrm{C}$ (optimal temperature for growing rainbow trout Oncorhynchus mykiss). Environmental isolates were grown in liquid media containing ammonium or nitrite, and best strains in terms of growth and ammonium or nitrite removal were identified via 16S rRNA sequencing. Dyadobacter sp. (no. 68) and Janthinobacterium sp. (no. 100) were selected for optimal adaptation to growth at $15^{\circ} \mathrm{C}$ and best ammonium and nitrite removal $(P<0.05)$, respectively. A heterotrophic ammonium and nitrite removal (HAN) microbial complex, containing selected strains, was prepared and applied in a trout culture system. After 10 days, the effect of microbial HAN complex was investigated in terms of ammonium and nitrite removal, as well as stress and immune indices present in the plasma of cultivated trout. Compared to a standard cultivation setup, addition of the HAN complex had a clear beneficial effect on keeping the un-ionized ammonia and nitrite level below prescribed standards $(P<0.05)$. This resulted in reduction of stress and immune reactions of cultivated fish $(P<0.05)$, leading to an augmentation of final weight and survival. Application of the selected microbial complex resulted in a significant improvement of the aquaculture ecosystem.
\end{abstract}

Keywords Rainbow trout (Oncorhynchus mykiss) · Heterotrophic bacteria · Ammonium and nitrite removal · Cold adaptation · Stress · Innate immune response

\section{Introduction}

Aquaculture associated to inland water sources is one of the most intensely growing industries, and its growth potential is

Electronic supplementary material The online version of this article (https://doi.org/10.1007/s00248-020-01498-6) contains supplementary material, which is available to authorized users.

Gholamreza Rafiee

ghrafiee@ut.ac.ir

$\triangle \quad$ Ivan Mijakovic

ivan.mijakovic@chalmers.se

1 Department of Fisheries Sciences, Faculty of Natural Resources, University of Tehran, Karaj 331585-4314, Iran

2 Division of Systems \& Synthetic Biology, Department of Biology and Biological Engineering, Chalmers University of Technology, Kemivägen 10, 41296 Gothenburg, Sweden

3 Novo Nordisk Foundation Center for Biosustainability, Technical University of Denmark, 2800 Lyngby, Denmark limited by availability of freshwater sources worldwide [1, 2]. Reusing water is one of the solutions proposed to reduce water consumption in aquaculture. However, the water contains high levels of ammonium, which represents an obstacle for fish breeding [3-5]. Ammonia and nitrite are recognized as the major environmental stressors for fish [6, 7]. Exposure to such stressors results in physiological responses leading weakness in their immune system, which makes them more prone to infections $[6,8]$ and reduces overall growth and production yield [9].

Attempts have been made to operate freshwater fish farming using some level of water recycling, such as minimal water exchange or recirculating aquaculture systems (RAS) $[10,11]$. Nitrification is a microbial process that could be used to reduce or eliminate unwanted nitrogen in recycled water for aquaculture [12-14], and thus make water recycling feasible on a larger scale. Nitrification can be performed in two forms, with autotrophic and heterotrophic bacteria $[15,16]$, and these bacteria can sometimes work in association [16, 17]. It has 
been reported that autotrophic ammonium and nitrite removal occurs more rapidly in the presence of heterotrophic strains [18-23].

Rainbow trout (Oncorhynchus mykiss) is one of the major cold water species growing worldwide [24]. Trout are generally on-grown in raceways or ponds supplied with flowing water, but some are produced in cages and recirculating aquaculture systems (RAS). In these systems, biofilters based on microorganisms convert harmful components such as ammonium to nitrite and nitrate [25]. The suitable growth temperature for most aerobic heterotrophic species used in biofilters is $28^{\circ} \mathrm{C}$ [26], whereas the optimal temperature for trout culture is around $15^{\circ} \mathrm{C}$ [17]. Therefore, there is a considerable challenge of finding microorganisms that can grow and efficiently remove ammonium at lower temperatures required for trout aquaculture [27].

The purpose of this study was isolation and characterization of heterotrophic bacteria that remove ammonium and nitrite and can operate at lower temperatures. The aim was to apply such bacteria to rainbow trout culture systems operated at $15^{\circ} \mathrm{C}$, in order to improve environmental conditions in a rainbow trout recirculating aquaculture system and obtain higher production yields.

\section{Materials and Methods}

\section{Sampling}

Three different water sources were collected from different locations in Gothenburg, Sweden, including an artificial lake $\left(57^{\circ} 41^{\prime} 02.6^{\prime \prime} \mathrm{N}, 1^{\circ} 56^{\prime} 50.0^{\prime \prime} \mathrm{E}\right)$ (SDL), a river $\left(57^{\circ} 41^{\prime}\right.$ $\left.49.4^{\prime \prime} \mathrm{N}, 11^{\circ} 55^{\prime} 04.5^{\prime \prime} \mathrm{E}\right)(\mathrm{GR})$, and a natural lake $\left(57^{\circ} 40^{\prime}\right.$ $\left.42.4^{\prime \prime} \mathrm{N}, 12^{\circ} 03^{\prime} 25.7^{\prime \prime} \mathrm{E}, 57^{\circ} 40^{\prime} 42.4^{\prime \prime} \mathrm{N}, 12^{\circ} 03^{\prime} 25.7^{\prime \prime} \mathrm{E}\right)$ (DL) (Supplemental Fig. 1).

\section{Isolation of Ammonium and Nitrite Removing Bacteria}

Three milliliters of water samples collected from various sources was inoculated in $47 \mathrm{ml}$ of liquid medium adapted for ammonia-oxidizing bacteria (AOB) (containing $279 \mathrm{mg} \mathrm{l}^{-1}$ ammonium $[28,29]$ ) and $47 \mathrm{ml}$ of liquid medium adapted for nitrite-oxidizing bacteria (NOB) (containing $427 \mathrm{mg} \mathrm{l}^{-1}$ nitrite $[30,31]$ ) and grown in 100-ml sterile flasks at $30{ }^{\circ} \mathrm{C}$. The media were modified by addition of $330 \mathrm{mg} \mathrm{l}^{-1}$ glucose and $60 \mathrm{mg} \mathrm{l}^{-1}$ peptone as the carbon sources. After 2 weeks, old media were replaced with fresh ones. After 30 days, the cultures were serially diluted up to $10^{-8}$ and grown on AOB and NOB plates (containing $13 \mathrm{~g} \mathrm{l}^{-1}$ agar powder, bacteriological). Colonies potentially related to ammonium and nitrite removal were isolated and cultured separately.

\section{Bacterial Growth and Ammonium or Nitrite Removal Activities}

Colonies were grown in liquid $\mathrm{AOB}$ and $\mathrm{NOB}$ media for 5 days and then subcultured in 96-well plates at $30{ }^{\circ} \mathrm{C}$. Absorbance at $600 \mathrm{~nm}$ was monitored every $30 \mathrm{~min}$ for 10 days in growth profiler (EnzyScreen Growth Profiler 960). For the selected colonies, ammonium and nitrite concentrations were measured using Hach spectrophotometer DR 3900 (according to the manufacturer's protocol: LCK340 kits for nitrate assay, LCK303 for ammonium assay and LCK339 for nitrite assay).

\section{Identification of Bacterial Strains}

Genomic DNA of selected bacteria was extracted using DNeasy UltraClean Microbial Kit (Qiagen). The $16 \mathrm{~S}$ rRNA fragments were amplified using a thermocycler (c1000 touch thermal cycler, BioRad, USA) after preparation with primstar PCR kit, using the following primers: 5'AGA GTT TGA TCC TGG CTC AG-3' and 5'-GGT TAC CTT GTT ACG ACT T-3'. The size and quality of $16 \mathrm{~S}$ rRNA fragments (expected size $1.5 \mathrm{~kb}$ ) were checked by agarose gel electrophoresis (Supplemental Fig. 2). After a nano-drop quality assay, PCR-amplified 16S rRNA samples were sequenced (Eurofins, Germany) using the same forward and reverse primers that were used for amplification. The forward and reverse sequencing results were assembled using snap gene software and bacterial strains were identified using the blast portal (https://blast.ncbi. nlm.nih.gov/Blast.cgi). A phylogenetic tree was constructed by neighbor-joining method, and reliability of each node was established by bootstrap methods using MEGA4 software.

\section{Adaptation to Cold Temperature}

Following the screening steps, the selected strains were adapted to low temperature. The strains were first grown at $30{ }^{\circ} \mathrm{C}$ for 3 days, then at RT (room temperature, $22.3 \pm 2.8^{\circ} \mathrm{C}$ ) for 2 weeks, and finally at $15^{\circ} \mathrm{C}$ for 2 weeks.

\section{Microscopy Slide Preparing of Isolated Bacteria}

$1.2 \%$ agarose was completely dissolved in Tris- $\mathrm{HCl}(50 \mathrm{mM})$ by heating. The microscope slides were floated in agarose solution and then $5 \mu$ of bacterial suspension was transferred onto the slides. The slides were covered by cover glass and observed under an optical microscope $(\times 1000$ combined magnification). 


\section{Rainbow Trout Cultivation}

The selected and adapted heterotrophic ammonium and nitrite removing bacteria (HAN) were mixed at a ratio of 2.5:1 (ammonium removing bacteria: nitrite removing bacteria) [32] at a dilution of $8.1 \times 10^{9} \mathrm{CFU} / \mathrm{ml}$. One liter of HAN mix was transferred to a 400-1 tank containing 50 rainbow trout (50.65 $\pm 3.89 \mathrm{~g})$, at $14.5 \pm 1.2{ }^{\circ} \mathrm{C}(n=3)$. Negative control group tanks was selected without adding bacteria to the tanks ( $n=$ 3). HAN (bacterial complex) and negative control tanks were filled with water before the trout were added to each tank. Ammonium, nitrite, and nitrate concentrations were monitored for 10 days. The fish were fed once per day (1\% body weight) with fish feed $(\mathrm{CP}=38.7 \pm 2.8)$. During the feeding period, water was not replaced, and only water evaporation (1-2\% per day) was compensated. Each tank was a recirculating system with a $30 \mathrm{~W}$ waterproof pump at the bottom of each tank. Water from the bottom of each tank was pumped through a filter (containing washed sand, glass wool, and $2 \mathrm{~cm}^{2}$ sponge particles) at the bottom of the tank and after filtration, it was returned into the tank. For aeration, a central air compressor was connected to each tank via an aquarium water hose connected to ceramic air stones $(40 \mathrm{~mm} \times$ $15 \mathrm{~mm})$.

\section{Blood Sampling}

At the end of the breeding period, after $24 \mathrm{~h}$ of starvation, three fish from each experimental unit were randomly sampled. For this purpose, the fish were first anesthetized using benzocaine $[33,34]$ and then completely dried. Blood sampling from their caudal vein was performed using a 5-ml heparin syringe. Then, a part of each blood sample was centrifuged at $6000 \mathrm{~g}$ for $8 \mathrm{~min}$ to obtain plasma. The collected sera were stored at $-80^{\circ} \mathrm{C}$ until the desired parameters were measured. The remaining blood samples were used for investigation of hematological parameters.

\section{Immunological and Stress Indicators}

Immunological and stress indicators were measured from the obtained sera according to previously described protocols. The assays included quantification of lysozyme as described by Demers and Bayne [35], total protein as described by Nonaka, Iwaki, Nakai, Nozaki, Kaidoh, Natsuume-Sakai, and Takahashi [36], respiratory burst activity as described by Secombes [37], bacterial activity as described by Budiño, Cal, Piazzon, and Lamas [38], complementary activity assay as described by Yano [39], total immunoglobulin as described by Siwicki and Anderson [40], glucose measurement according to Pottinger and Carrick [41], and cortisol assay as described by Pickering, Pottinger, and Sumpter [42].

\section{Hematological Parameters}

Hematocrit, hemoglobin, and number of red blood cells were measured in all experimental groups. Mean corpuscular volume (MCV), mean corpuscular hemoglobin $(\mathrm{MCH})$, and mean corpuscular hemoglobin concentration $(\mathrm{MCHC})$ were measured using the following formulas [43, 44].

$$
\begin{gathered}
\mathrm{MCV}=\mathrm{Ht} \times \frac{1000}{\mathrm{RBC}} \\
\mathrm{MCH}=\mathrm{Hb} \times \frac{10}{\mathrm{RBC}} \\
\mathrm{MCHC}=\frac{\mathrm{Hb}}{\mathrm{Ht}}
\end{gathered}
$$

\section{Statistical Analysis}

The normality of data was assessed by the KolmogorovSmirnov test. One-way analysis of variance (one-way ANOVA) was used for comparing data means. The significance level between treatments was determined by the Tukey test at $5 \%$ level. Statistical analysis was performed by SPSS 17 software in the Windows environment.

\section{Ethics}

Ethical permission for the research obtained from the Ethics Committee of the University of Tehran.

\section{Results}

In order to isolate bacteria that can thrive at low temperature and effectively remove ammonium and nitrite, water samples were collected from three different water sources in Gothenburg, Sweden (Supplemental Fig. 1). Freshwater sources included a river (GR), and a natural (DL) and artificial lake (SDL). After water sampling from different locations, water quality indicators were measured in all collected samples (Table 1). The results

Table 1 Water quality indicators in collected samples from different water sources

\begin{tabular}{llll}
\hline Indicator & \multicolumn{2}{l}{ Water sources } & \\
\cline { 2 - 4 } & GR & SDL & DL \\
\hline $\mathrm{pH}$ & 7.3 & 7.6 & 7.4 \\
Temperature ${ }^{\circ} \mathrm{C}$ & $4^{\circ}$ & $4^{\circ}$ & $4^{\circ}$ \\
$\mathrm{NH}_{4}-\mathrm{N}\left(\mathrm{mg} \mathrm{l}^{-1}\right)$ & 0.135 & 0.051 & 0.006 \\
$\mathrm{NO}_{2}-\mathrm{N}\left(\mathrm{mg} \mathrm{l}^{-1}\right)$ & 0.026 & 0.024 & 0.025 \\
$\mathrm{NO}_{3}-\mathrm{N}\left(\mathrm{mg} \mathrm{l}^{-1}\right)$ & 0.079 & 0.352 & 0.053 \\
\hline
\end{tabular}

Artificial lake (SDL), river (GR), and a lake (DL) 
a

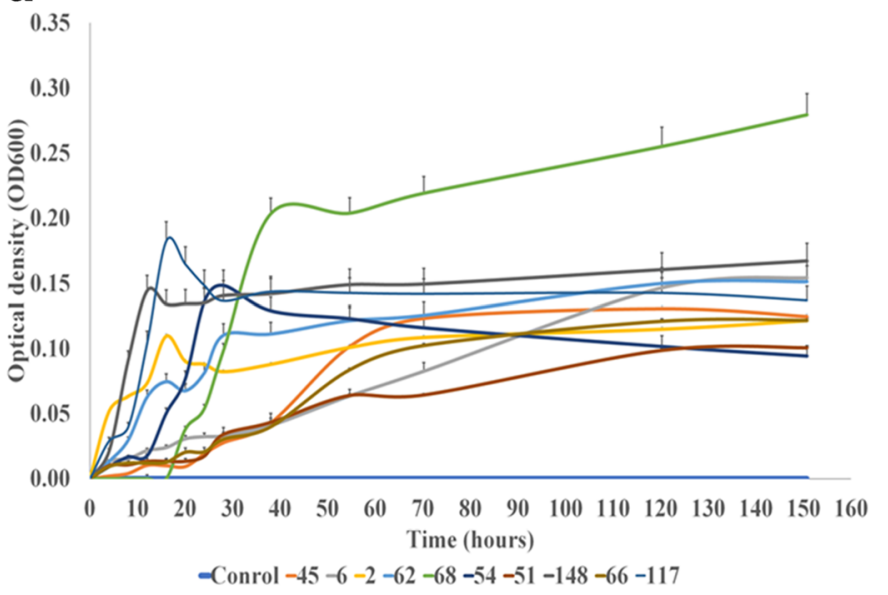

C

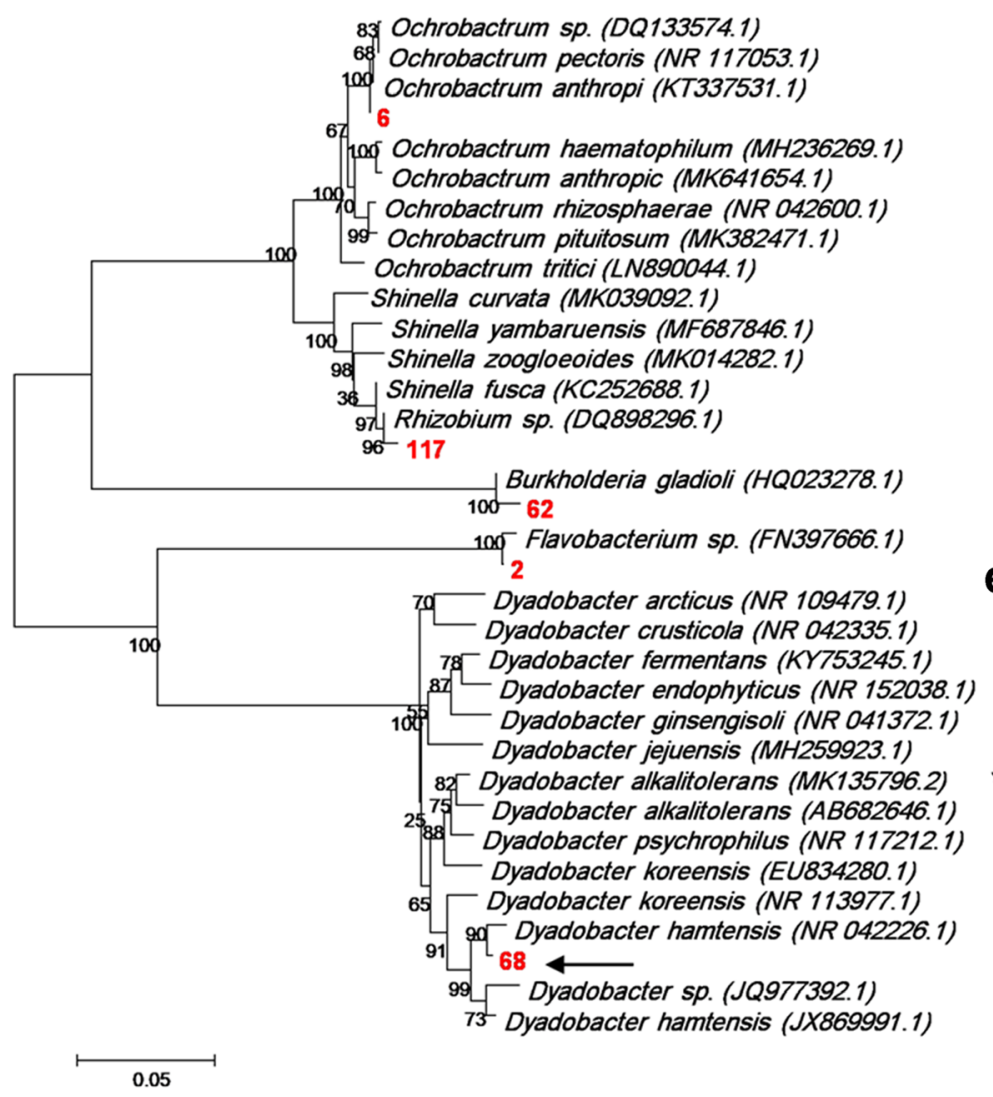

b

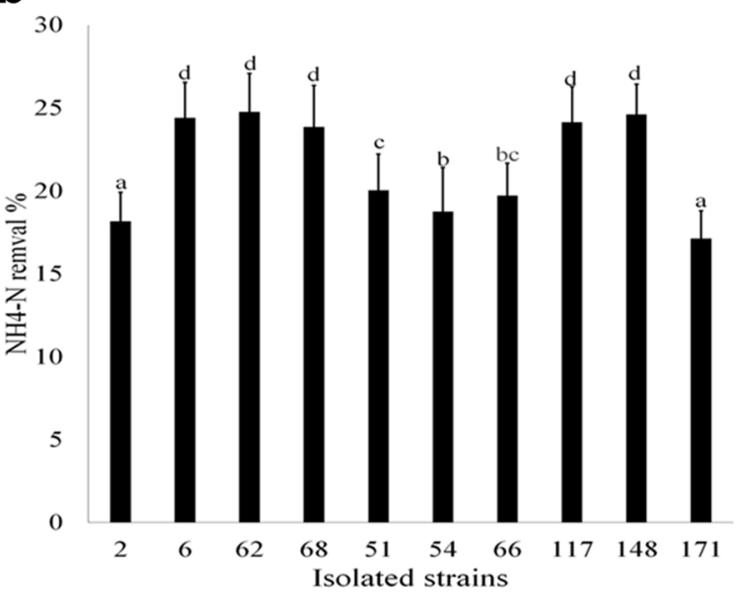

d

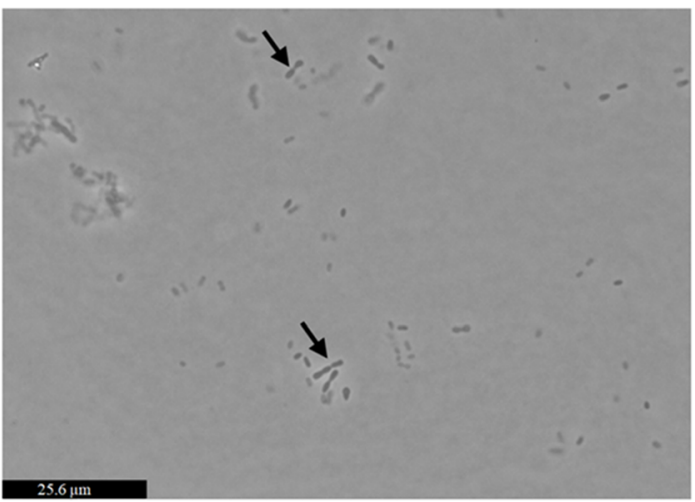

e

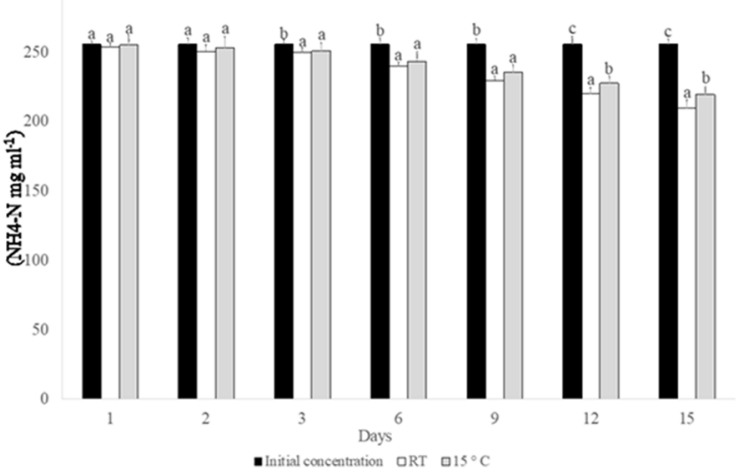

Fig. 1 a Growth rate of isolated heterotrophic ammonium removing bacteria for 10 days. b Ammonium removal activity of selected bacteria after 10 days. c Phylogenetic tree of ammonium removing bacteria

showed that different water sources had different concentration of ammonium, nitrite, and nitrate. Among the samples, the DL water contained the lowest ammonium concentration $\left(0.006 \mathrm{mg}^{-1}\right)$, followed by SDL $\left(0.051 \mathrm{mg} \mathrm{l}^{-1}\right)$ and GR $\left(0.135 \mathrm{mg} \mathrm{l}^{-1}\right)$ water. Nitrite is the most ephemeral form of nitrogen which is rapidly converted to other products. Nitrite concentrations were similar in all samples. isolated in this study. d Microscopic observation of Dyadobacter sp. e Ammonium removal activity of Dyadobacter sp. at different temperatures

\section{Isolation and Characterization}

of Ammonium-Removing Dyadobacter sp. (no. 68) and Nitrite-Removing Janthinobacterium sp. (no. 100)

To find a solution for accumulation of unwanted ammonium and nitrite in an aquaculture system, bacterial strains with optimal growth at $15{ }^{\circ} \mathrm{C}$ and ammonium and nitrite removal ability were isolated and identified. Among the selected 


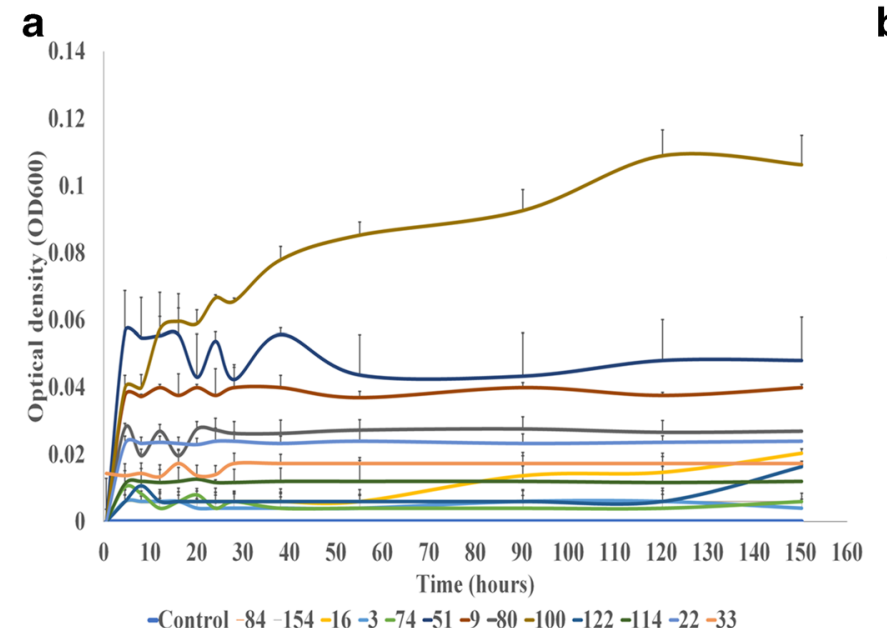

-Control -84-154-16-3 -74 -51 -9 -80 -100 -122 -114 -22 -33

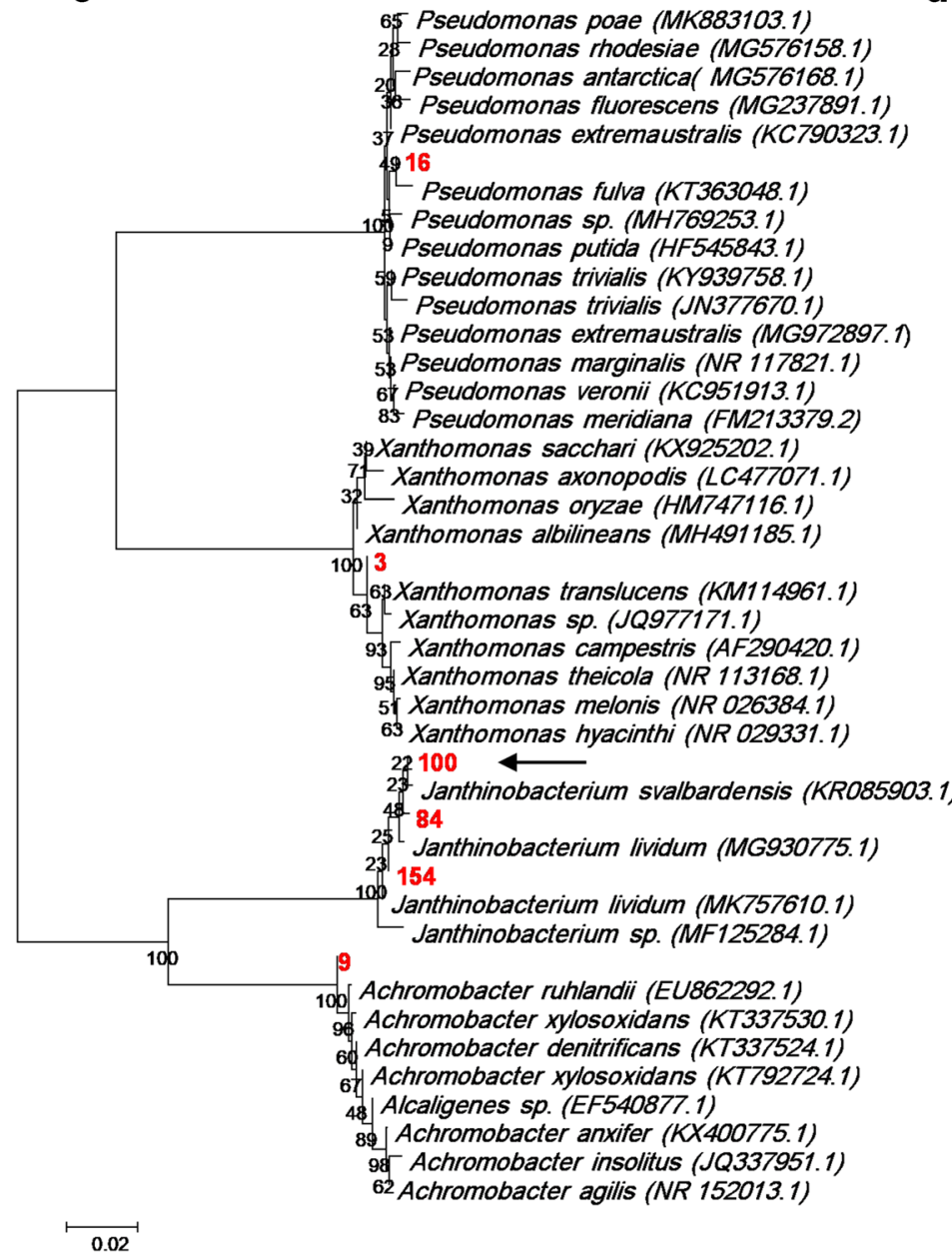

d
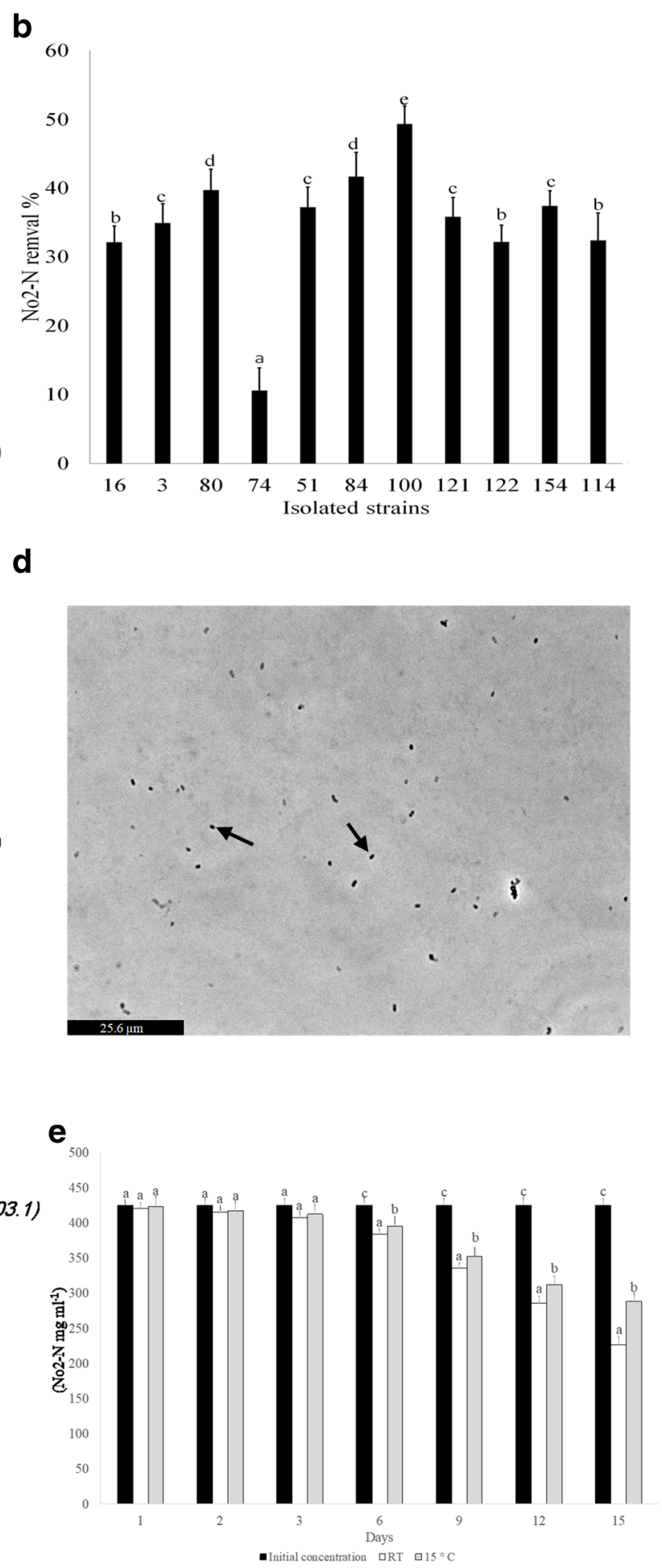

Microscopic observation of Janthinobacterium sp. e Nitrite removal activity of Janthinobacterium sp. at different temperatures

performer in terms of growth and ammonium removal activity (Fig. 1a, b). Interestingly, strain no. 68 was isolated from the water source collected from DL region with lowest ammonium concentration. Since the use of a new strain in aquaculture 
Table 2 The effect of heterotrophic ammonium and nitrite removal set (HAN) on concentration of un-ionized ammonia, nitrite, nitrate, dissolved oxygen, $\mathrm{pH}$, and temperature in a rainbow trout $(n=50)$ breeding system after 9 days. Recommended limits according to Timmons and Ebeling [48]

\begin{tabular}{|c|c|c|c|}
\hline \multirow[t]{2}{*}{ Indicators } & \multicolumn{3}{|l|}{ Group } \\
\hline & $\mathrm{HAN}^{*}$ & Control & Range limit \\
\hline NH3-N $\mu \mathrm{g}^{-1}$ & $8.8 \pm 1.8^{\mathrm{a}}$ & $13.2 \pm 2.1^{\mathrm{b}}$ & 12.5 \\
\hline $\mathrm{NO} 2-\mathrm{N} \mu \mathrm{g} 1^{-1}$ & $62 \pm 11^{\mathrm{b}}$ & $31 \pm 15^{\mathrm{a}}$ & 1000 \\
\hline NO3-N mg $1^{-1}$ & $15.61 \pm 5.36^{\mathrm{b}}$ & $13.13 \pm 4.12^{\mathrm{a}}$ & $<400$ \\
\hline Temperature ${ }^{\circ} \mathrm{C}$ & $14.15 \pm 1.17$ & $14.13 \pm 1.17$ & $<16$ \\
\hline $\mathrm{pH}$ & $6.85 \pm 0.09^{\mathrm{b}}$ & $6.25 \pm 0.17^{\mathrm{a}}$ & $6.5-8.5$ \\
\hline Dissolved oxygen $\left(\mathrm{mg} \mathrm{l}^{-1}\right)$ & $8.65 \pm 2.12$ & $8.51 \pm 3.19$ & $>6$ \\
\hline
\end{tabular}

The table shows values of mean $\pm \mathrm{SD}$ of three experimental repetitions. Values within the same row with different superscript differ significantly $(p<0.05)$

*Heterotrophic ammonium and nitrite removal set (HAN)

system is restricted and one should avoid strains that may infect the fish, the selected strains need to be identified prior to application. Among the isolated heterotrophic ammonium removing bacteria, strains no. 2, 6, 62, 68, and 117 were identified using 16S rRNA sequencing (Supplemental Fig. 3). Figure 1c shows the phylogenetic tree of different heterotrophic ammonium removing species that were isolated in this study. The phylogenetic tree revealed the most closely related relatives of the selected ammonium removing strains. It has shown that the closest evolutionary strain with $94.62 \%$ similarity to the best performing strain no. 68 was Dyadobacter hamtensis (NR 042226.1) (marked by black arrow in Fig. 1c). Microscopic observation of this strain showed that the cells aggregate in chains which can be helpful for biofloc formation in biofilters and thereby suitable for aquaculture wastewater treatment (Fig. 1d). The isolated strain of Dyadobacter sp. (no. 68) is not pathogenic and based on the growth profile and ammonium removal activity, it was selected as the best candidate for further analysis.

All selected environmental strains exhibited some capacity to remove nitrite, with their activity ranging from

Table 3 Rainbow trout growth and survival in different experimental groups (HAN and control) in breeding system after 9 days

\begin{tabular}{llll}
\hline Group & \multicolumn{3}{l}{ Indicators } \\
\cline { 2 - 4 } & Initial weight $(\mathrm{g})$ & Final weight $(\mathrm{g})$ & Survival \\
\hline Control & $50.65 \pm 3.89$ & $57.75 \pm 3.39^{\mathrm{a}}$ & $72.25 \pm 6.21^{\mathrm{a}}$ \\
HAN $^{*}$ & $50.65 \pm 3.89$ & $60.75 \pm 4.57^{\mathrm{b}}$ & $86.4 \pm 7.29^{\mathrm{b}}$ \\
\hline
\end{tabular}

The table shows values of mean $\pm \mathrm{SD}$ of three experimental repetitions. Values within the same columns with different superscript differ significantly $(p<0.05)$

*Heterotrophic ammonium and nitrite removal set (HAN)
10.57 to $49.37 \%$ nitrite removed from the medium in 10 days (Fig. 2b). Among the selected environmental strains, no. 100 exhibited the best growth and highest nitrite removal activity (Fig. 2a). The group of best performers, among heterotrophic nitrite removing bacteria, strains no. 3 (GR), 9 (SDL), 16 (GR), 84 (SDL), 100 (GR), and 154 (DL) were identified using 16S rRNA sequencing (Supplemental Fig. 4). Figure 2c shows the phylogenetic tree of all heterotrophic nitrite removing species isolated in the current study. Phylogenetic tree showed that among the selected nitrite removing strains, 84, 100, and 154 were close to Janthinobacterium genus which can suggest a link between the performance of this genus and nitrite removal. Furthermore, it indicated that the closest strain with $95.33 \%$ similarity to strain no. 100 was non-pathogenic Janthinobacterium svalbardensis (KR 085903.1) (marked by black arrow in Fig. 2c, D). Therefore, this strain was selected for further analysis as the optimal nitrite remover. It was already reported that the genus Janthinobacterium exhibited an impressive heterotrophic nitrifying efficiency with significant nitrite removal activity $[45,46]$. Therefore, it can reduce nitrite to nitric oxide by the nitrite reductase proteins [47].

\section{Adaptation of Dyadobacter sp. and Janthinobacterium sp. to $15^{\circ} \mathrm{C}$}

Different bacterial strains may not have the ability to adapt and perform certain metabolic processes at low temperatures. On the other hand, rainbow trout is a cold water fish; therefore, the selected strains need to operate at $15{ }^{\circ} \mathrm{C}$ in order to be successfully implemented in trout aquaculture. To examine the ammonium removal activity at lower temperatures, the isolated Dyadobacter sp. and Janthinobacterium sp. were grown at RT (room temperature, $22.3 \pm 2.8{ }^{\circ} \mathrm{C}$ ) and $15{ }^{\circ} \mathrm{C}$. The results showed that Dyadobacter sp. retained sufficient ammonium removal activity at lower temperatures (Fig. 2e). The ammonium removal activity commenced around day 6 and continued progressively to day 15 . Among the strains isolated in this study, Dyadobacter had the highest efficiency of ammonium removal and hence, it was selected for further experiments in trout culturing system. For Janthinobacterium sp., the results showed nitrite removal activity at $15{ }^{\circ} \mathrm{C}$ and RT starting from day 3. From day 3 until day 9 , there was no significant difference in nitrite removal between RT and $15{ }^{\circ} \mathrm{C}$. On days 12 and 15 , the highest nitrite removal activity of 11.6 and $13.25 \mathrm{mg} \mathrm{l}^{-1}$ day was observed in RT samples, respectively. This investigation indicated that Janthinobacterium sp. was able to perform effective nitrite removal at both RT and $15{ }^{\circ} \mathrm{C}$ (Fig. 2e) and represents a good candidate for implementation in trout culturing systems. 
Table 4 Hematological indices (mean corpuscular volume (MCV), mean corpuscular hemoglobin $(\mathrm{MCH})$, and mean corpuscular hemoglobin concentration (MCHC)) in different rainbow trout experimental groups (HAN and control) after 9 days

\begin{tabular}{llllll}
\hline Group & \multicolumn{5}{l}{ Indicators } \\
\cline { 2 - 5 } & Hemoglobin $(\mathrm{g} / \mathrm{dl})$ & Hematocrit $\%$ & $\mathrm{RBC}\left(10^{6} \mu \mathrm{l}^{-1}\right)$ & $\mathrm{MCV}(\mathrm{fl})$ & $\mathrm{MCHC} \%$ \\
\hline Control & $63.75 \pm 2.21$ & $39.5 \pm 1.29$ & $1.24 \pm 0.03$ & $318.68 \pm 12.59$ & $51.41 \pm 1.45$ \\
HAN* $^{*}$ & $59.5 \pm 1.5$ & $38 \pm 1.81$ & $1.25 \pm 0.014$ & $304.04 \pm 8.23$ & $47.60 \pm 1.15$ \\
\hline
\end{tabular}

The table shows values of mean $\pm \mathrm{SD}$ of three experimental repetitions. Values within the same columns with different superscript differ significantly $(p<0.05)$

*Heterotrophic ammonium and nitrite removal set (HAN)

\section{Ammonium and Nitrite Levels in Rainbow Trout Culture Were Reduced in the Presence of Dyadobacter sp. and Janthinobacterium sp.}

To determine the ammonium and nitrite removal activity of selected cold-adapted bacteria in trout culture, fresh colonies of Dyadobacter sp. (no. 68) and Janthinobacterium sp. (no. 100) were used to inoculate AOB and NOB liquid media and grown for 2 weeks, respectively. The culture of Dyadobacter sp. (no. 68) and Janthinobacterium sp. (no. 100) were applied to the trout breeding system as a mixed culture (Dyadobacter sp. (no. 68) to Janthinobacterium sp. (no. 100) ratios, 2.5:1) [32]. After 9 days, un-ionized ammonia and nitrite removal activity of the mixed culture was investigated. As expected, the results showed that the unionized ammonia concentration in untreated negative control group was above the recommended limits for trout culture. The un-ionized ammonia level in HAN group $\left(8.8 \pm 1.8 \mu \mathrm{g} \mathrm{l}^{-1}\right)$ was significantly lower compared to the control $(13.2 \pm 2.1)(P<0.05)$. This indicated that Dyadobacter sp. was functional in removing un-ionized ammonia in aquaculture system (Table 2) and it is capable of bringing the un-ionized ammonia levels below the recommended limit for trout culture. The results also showed a significant increase of nitrite and nitrate in HAN-treated group compared to the control. In the HAN treatment group, Dyadobacter sp. is expected to remove ammonium by converting it to nitrite. As a result, nitrite accumulation could be expected, which is harmful to trout culture [49]. However, nitrite accumulated as a product of Dyadobacter sp. activity was effectively removed by Janthinobacterium sp. in our HAN microbial complex, resulting in $62 \pm$ $11 \mu \mathrm{g} \mathrm{l}^{-1}$ nitrite concentration in the treatment group which is below the range limit value $\left(1000 \mu \mathrm{g}^{-1}\right)$ (Table 2). $\mathrm{pH}$ value was lower in the control group in comparison with the HAN group (Table 2). It was previously reported that hydroxamic acids get produced under heterotrophic nitrification $[50,51]$. Thus, $\mathrm{pH}$ decrease in HAN group might be due to the acid production during nitrification in this experimental group. Other water quality indices such as dissolved oxygen and temperature did not show any significant differences between the groups.

\section{Trout Stress Was Alleviated, and Aquaculture Productivity Increased in the HAN-Treated Group}

Environmental disturbances in aquaculture can lead to increased growth of opportunistic pathogens and decreased appetite of the fish, that negatively affect growth and survival $[52,53]$. The trout growth in HAN-treated group increased compared to the control group. The results also showed that the survival rate in the HAN-treated population was higher than in the control group, and the observed differences were statistically significant (Table 3 ).

Fish gills are responsible for oxygen uptake, and the oxygen is subsequently transported to different fish organs. Any abnormality in fish respiratory system can affect the hematological parameters. Thus, we have investigated these parameters in HAN-treated fish compared to the control group. The results of blood indices showed that hemoglobin, $\mathrm{MCV}, \mathrm{MCHC} \%$, and hematocrit were higher in the control group compared with the HAN-treated group (Table 4). Red blood cell numbers showed no significant differences between the groups. Increased un-ionized ammonia level can result in fish respiratory disorders in a fish farming environment. Therefore, hemoglobin and hematocrit increase observed in the control group might be correlated with the need to increase of oxygen carrying capacity. However, further investigation of these strains for longer treatment periods and with higher fish density will be required to test this hypothesis.

Environmental sources of stress can be broadly divided into acute (short time, high concentration ratio) and chronic (long time, low stress ratio). In a chronic stress, when cortisol level rises, the body energy goes up through the glucose increase, and innate immune is suppressed [54]. Stressors, such as ammonium and nitrite, cause systemic shocks. In this study, the groups were under stress. Our results showed that the glucose and cortisol levels in HAN-treated group were lower than the control at the end of the experiment (Fig. 3), indicating that the fish experienced less environmental stress in HAN-treated group. Growth of opportunistic pathogens also increase in stress conditions [55]. This typically triggers immune system 
a

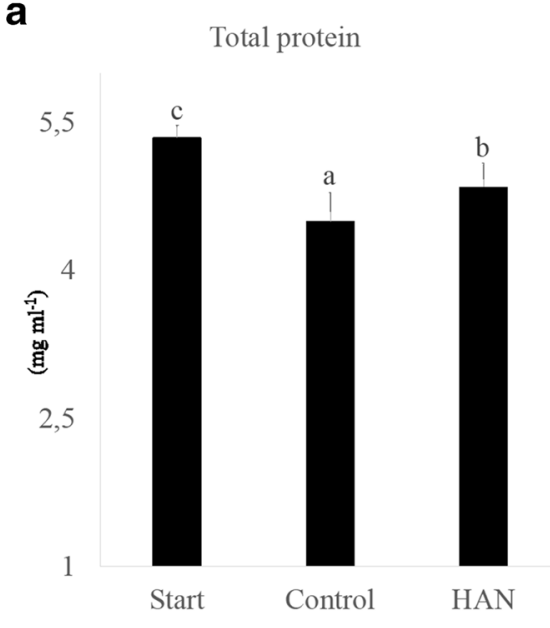

d

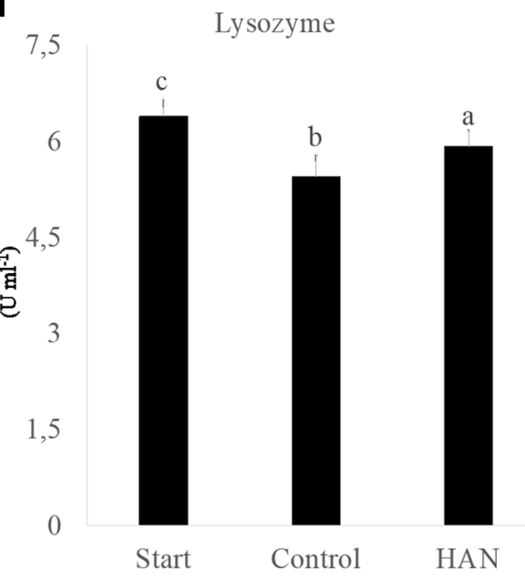

g

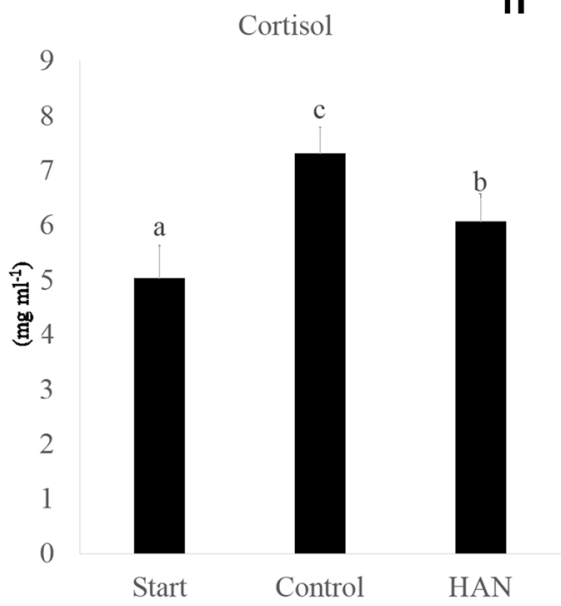

Fig. 3 Comparison (mean $\pm \mathrm{SD}$ ) of total protein (a), total globulin (b), complement activity $(\mathbf{c})$, lysozyme $(\mathbf{d})$, respiratory burst activity (e), bacterial activity (f), cortisol (g), and glucose (h) in rainbow trout sera

response. Therefore, we have investigated the innate immune response of trout in HAN-treated group compared with the control group. The results showed that the total plasma protein, total globulin, complement activity,
120

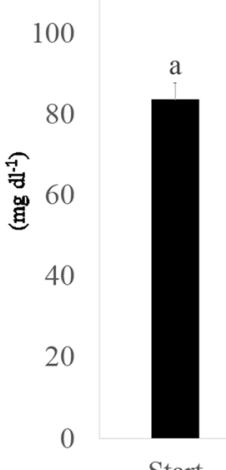

C
C $0,6 \quad$ Complement activity

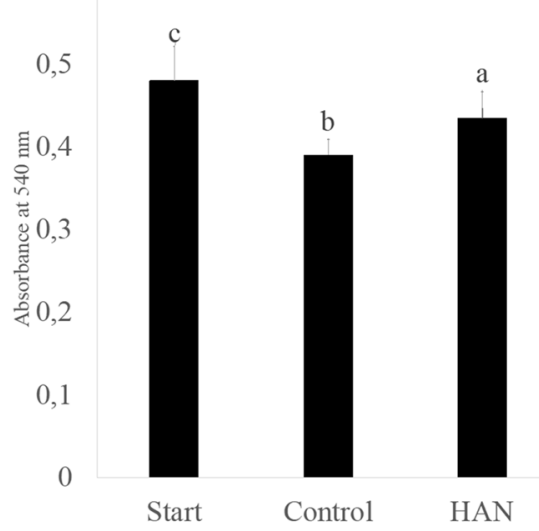

f 0,5 Bacterial activity

0,45

0,4

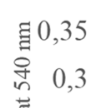

ช 0,25

: 0,2

\& 0,15

0,1

0,05

0
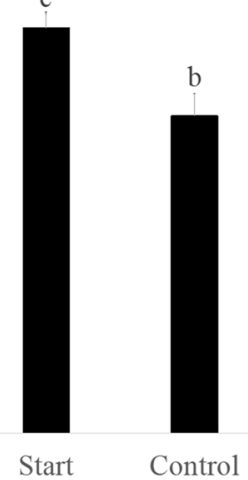

a

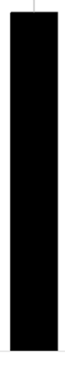

HAN

Glucose

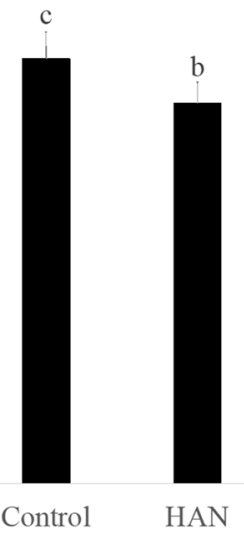

exposed to microbial complex after 9 days. Start (starting point), control (no microbial complex), and HAN (microbial complex of Dyadobacter sp. + Janthinobacterium sp. $)(P<0.05)$

lysozyme, respiratory burst activity, and bacterial activity in control group were lower than HAN group at the end of the experiment (Fig. 3), also corroborating the notion that HAN-treated group experienced less stress. 


\section{HAN treatment \\ $J$. svalbardensis $+D$. hamtensis \\ Control}

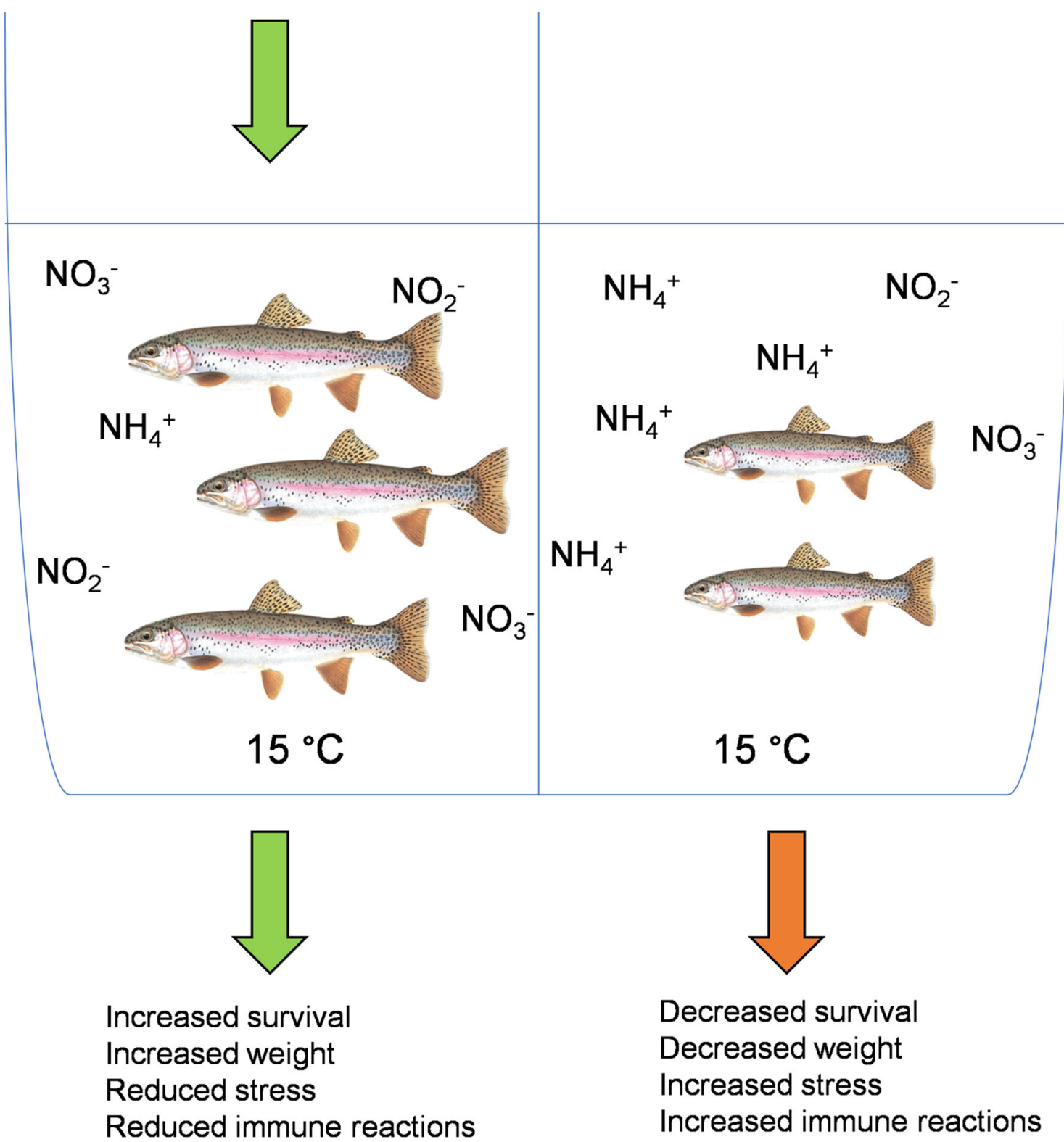

Fig. 4 Schematic summary on application of HAN (microbial complex of Dyadobacter sp. + Janthinobacterium sp.) in on survival, weight, stress, and immune reactions

\section{Discussion}

In a RAS system, biological filters are usually used to reduce ammonia. Ammonia is available in two forms, as un-ionized ammonia and ionized ammonium. In terms of toxicity, the un-ionized form is important for aquatic animals [56]. As both groups of heterotrophic and autotrophic bacteria have nitrification ability [56], there is a competition for nitrification between these two groups in a RAS system. Heterotrophic bacteria win this competition for nitrification when dissolved organic carbon (DOC) to nitrogen ratio increases [56, 57]. This ratio could be increased by the activity of heterotrophic bacteria, Accumulation of dead bacteria as well as ammonia assimilation into microbial biomass $[57,58]$. It has been reported that by increasing this ratio heterotrophic nitrifiers could have five times higher growth and 2-3 times higher activity compared to autotrophic bacteria [59]. In the current study, heterotrophic Dyadobacter sp. and Janthinobacterium sp. from environmental isolates were 
applied for un-ionized ammonia and nitrite removal in trout culture system, respectively.

Prior studies showed that $D$. hamtensis is lipase, maltose, gelatinase and urease negative, glucose, arabinose, galactose and xylose positive, and possesses fermentation ability [60]. The studies have also reported that this species can grow at lower temperatures [60]. It has been previously demonstrated that Dyadobacter species can perform denitrification [61]. For example, it was shown that $D$. fermentans and D. soli MJ20 are capable of ammonium consumption [62]. In nature, distinct strategies are adopted by microorganisms to cope with nitrogen starvation. Dyadobacter can even grow on Ndeficient Burk medium due to its ability of $\mathrm{N}_{2}$ fixation [63]. However, in our study, ammonium was the only available nitrogen source in the medium for Dyadobacter and it was evidently able to grow on it and remove ammonium from the ammonium-enriched medium. Our results suggest that despite a modest decrease of activity at $15^{\circ} \mathrm{C}$, this species can effectively lower ammonium concentration in aquaculture.

The genus Janthinobacterium has been isolated from many different water and soil sources so far [64-66]. It has optimal growth at $15^{\circ} \mathrm{C}$ and it can also grow at temperatures as low as $2{ }^{\circ} \mathrm{C}$, with a pH of 6.8 [67]. This genus is glucose and oxidasepositive, but indole and lactose negative [67]. Members of this genus are known to degrade nitrite at low temperatures [46]. Several studies report antifungal and antibacterial roles of the Janthinobacterium genus [68-71]. These roles are very important in aquaculture systems where opportunistic pathogens are a constant threat.

Some of the major environmental pollutants in trout culture are un-ionized ammonium (ammonia) and nitrite [72]. Ammonia is produced by protein catabolism in fish and excreted from the blood through the gills [73]. A decline in growth, tissue erosion (kidney, gill, and skin) and degeneration, immune suppression and high fish mortality is related to the accumulation of large amounts of ammonium in aquatic systems [74]. The results of the current study showed that selected bacterial complex decreased ammonia in trout culture system. In treated group, decreased mortality and increased growth was achieved. Furthermore, reduced stress and immune reactions in HAN-treated trout in comparison with the control group was observed. Stressors affect the activation of hypothalamus-pituitary-interrenal axis (HPI) in different organs, which is involved in immune and stress response in different species of teleost. Studies showed that although most fishes exhibit a general stress response, the pattern and magnitude of the response may be influenced by environmental factors such as ammonium, temperature, and salinity $[75,76]$. Similar to the results of our control setup, cortisol levels were previously found to be increased, and immune responses were decreased in changing or stressful conditions for aquatic species $[8,54,72]$.
In the present study, the HAN culture applied to the trout culture system effectively lowered the un-ionized ammonia concentration during trout cultivation. This resulted in improved physiological conditions of trout, with decrease in activation of immune system and enhanced growth (Fig. 4). Nitrite levels were kept in check by Janthinobacterium sp., despite the active ammonium to nitrite conversion by Dyadobacter sp., and they remained under acceptable limits at all times. Nitrogen immobilization may contribute to nitrogen removal in which microorganisms assimilate inorganic nitrogen such as ammonium and nitrite for the synthesis of proteins and other nitrogen-containing organic compounds $[77,78]$. This process occurs frequently when nitrogen-poor organic matter is decomposed [77, 79]. This nitrogen utilization mechanism could be also suggested as a hypothetic mechanism of nitrogen removal using these bacteria. Thus, it can be concluded that the combined use of Dyadobacter sp. and Janthinobacterium sp. can be recommended for rainbow trout culture systems, as it leads to a considerable improvement of farming conditions. Continued research is recommended by applying longer study period and higher fish density as well as performing further analysis eg additional fish growth indices (SGR, FCR) and oxidative stress analysis. Additionally, further investigation is required to study different mechanism of ammonium and nitrite removal by described heterotrophic microorganisms.

Funding Information This study was supported by the University of Tehran, Department of Fisheries Sciences; Chalmers University of Technology, Division of Systems \& Synthetic Biology, Department of Biology and Biological Engineering and Iran National Science Foundation. This work was also supported by a grant from the Carl Tryggers Foundation (CTS17:312).

Open Access This article is licensed under a Creative Commons Attribution 4.0 International License, which permits use, sharing, adaptation, distribution and reproduction in any medium or format, as long as you give appropriate credit to the original author(s) and the source, provide a link to the Creative Commons licence, and indicate if changes were made. The images or other third party material in this article are included in the article's Creative Commons licence, unless indicated otherwise in a credit line to the material. If material is not included in the article's Creative Commons licence and your intended use is not permitted by statutory regulation or exceeds the permitted use, you will need to obtain permission directly from the copyright holder. To view a copy of this licence, visit http://creativecommons.org/licenses/by/4.0/.

\section{References}

1. Kalbassi MR, Abdollahzadeh E, Salari-Joo H (2013) A review on aquaculture development in Iran. Ecopersia 1:159-178

2. Hoseinifar SH, Sun Y-Z, Wang A, Zhou Z (2018) Probiotics as means of diseases control in aquaculture, a review of current knowledge and future perspectives. Front Microbiol. 9:2429 
3. De Leão SR, Zaniboni-Filho E, Baldisserotto B (2009) Effect of combined non-ionized ammonia and dissolved oxygen levels on the survival of juvenile dourado, Salminus brasiliensis (Cuvier). J World Aquacult Soc 40:695-701

4. Thurston RV, Phillips GR, Russo RC, Hinkins SM (1981) Increased toxicity of ammonia to rainbow trout (Salmo gairdneri) resulting from reduced concentrations of dissolved oxygen. Can J Fish Aquat Sci 38:983-988

5. Person-Le Ruyet J, Chartois H, Quemener L (1995) Comparative acute ammonia toxicity in marine fish and plasma ammonia response. Aquaculture 136:181-194

6. Ackerman PA, Wicks BJ, Iwama GK, Randall DJ (2006) Low levels of environmental ammonia increase susceptibility to disease in Chinook salmon smolts. Physiol Biochem Zool 79:695-707

7. Lewis Jr WM, Morris DP (1986) Toxicity of nitrite to fish: a review. Trans Am Fish Soc 115:183-195

8. Neissi A, Rafiee G, Nematollahi M, Razavi SH, Maniei F (2015) Influence of supplemented diet with Pediococcus acidilactici on non-specific immunity and stress indicators in green terror (Aequidens rivulatus) during hypoxia. Fish Shellfish Immunol 45: 13-18

9. Russell N, Evans R, Ter Steeg P, Hellemons J, Verheul A, Abee T (1995) Membranes as a target for stress adaptation. Int J Food Microbiol. 28:255-261

10. Decamp O, Conquest L, Forster I, Tacon A (2002) The nutrition and feeding of marine shrimp within zero-water exchange aquaculture production systems: role of eukaryotic microorganisms. World Aquaculture Society: Microbial approaches to aquatic nutrition within environmentally sound aquaculture production systems

11. Van Rijn J (2013) Waste treatment in recirculating aquaculture systems. Aquac Eng 53:49-56

12. Foesel BU, Gieseke A, Schwermer C, Stief P, Koch L, Cytryn E, De La Torré JR, Van Rijn J, Minz D, Drake HL (2007) Nitrosomonas Nm143-like ammonia oxidizers and Nitrospira marina-like nitrite oxidizers dominate the nitrifier community in a marine aquaculture biofilm. FEMS Microbiol Ecol 63:192-204

13. Schreier HJ, Mirzoyan N, Saito K (2010) Microbial diversity of biological filters in recirculating aquaculture systems. Curre Opin Biotechnol 21:318-325

14. Stephen JR, McCaig AE, Smith Z, Prosser JI, Embley TM (1996) Molecular diversity of soil and marine 16S rRNA gene sequences related to beta-subgroup ammonia-oxidizing bacteria. Appl Environ Microbiol 62:4147-4154

15. Chen J, Han Y, Wang Y, Gong B, Zhou J, Qing X (2016) Start-up and microbial communities of a simultaneous nitrogen removal system for high salinity and high nitrogen organic wastewater via heterotrophic nitrification. Bioresour Technol 216:196-202

16. Chen Q, Ni J (2012) Ammonium removal by Agrobacterium sp. LAD9 capable of heterotrophic nitrification-aerobic denitrification. J Biosci Bioeng 113:619-623

17. Qu D, Wang C, Wang Y, Zhou R, Ren H (2015) Heterotrophic nitrification and aerobic denitrification by a novel groundwater origin cold-adapted bacterium at low temperatures. RSC Adv. 5: 5149-5157

18. Clark C, Schmidt E (1966) Effect of mixed culture on Nitrosomonas europaea simulated by uptake and utilization of pyruvate. J Bacteriol 91:367-373

19. Jones RD, Hood MA (1980) Effects of temperature, pH, salinity, and inorganic nitrogen on the rate of ammonium oxidation by nitrifiers isolated from wetland environments. Microb Ecol 6:339347

20. Su J-J, Yeh K-S, Tseng P-W (2006) A strain of Pseudomonas sp. isolated from piggery wastewater treatment systems with heterotrophic nitrification capability in Taiwan. Curr Microbiol 53:77-81
21. Robertson L, Cornelisse R, De Vos P, Hadioetomo R, Kuenen J (1989) Aerobic denitrification in various heterotrophic nitrifiers. Antonie Van Leeuwenhoek 56:289-299

22. Verstraete W, Focht D (1977) Biochemical ecology of nitrification and denitrificationAdvances in microbial ecology. Springer, pp. $135-214$

23. Sakai K, Ikehata Y, Ikenaga Y, Wakayama M, Moriguchi M (1996) Nitrite oxidation by heterotrophic bacteria under various nutritional and aerobic conditions. J Ferment Bioeng 82:613-617

24. FAO (2011) Cultured aquatic species information programme Oncorhynchus mykiss (Walbaum, 1792): Fisheries and aquaculture department

25. Cohen Y (2001) Biofiltration-the treatment of fluids by microorganisms immobilized into the filter bedding material: a review. Bioresour Technol 77:257-274

26. Tao W, He Y, Wang Z, Smith R, Shayya W, Pei Y (2012) Effects of $\mathrm{pH}$ and temperature on coupling nitritation and anammox in biofilters treating dairy wastewater. Ecol Eng 47:76-82

27. Taotao Z, Dong L, Huiping Z, Shuibo X, Wenxin Q, Yingjiu L, Jie $Z$ (2015) Nitrogen removal efficiency and microbial community analysis of ANAMMOX biofilter at ambient temperature. Water Sci Technol 71:725-733

28. Bollmann A, French E, Laanbroek HJ (2011) Isolation, cultivation, and characterization of ammonia-oxidizing bacteria and archaea adapted to low ammonium concentrationsMethods in enzymology. Elsevier, pp. 55-88

29. Verhagen FJ, Laanbroek HJ (1991) Competition for ammonium between nitrifying and heterotrophic bacteria in dual energylimited chemostats. Appl Environ. Microbiol 57:3255-3263

30. Spieck E, Lipski A (2011) Cultivation, growth physiology, and chemotaxonomy of nitrite-oxidizing bacteria. Methods in enzymology. Elsevier, pp. 109-130

31. Hankinson T, Schmidt E (1988) An acidophilic and a neutrophilic Nitrobacter strain isolated from the numerically predominant nitrite-oxidizing population of an acid forest soil. Appl Environ Microbiol. 54:1536-1540

32. Li B, Irvin S, Baker K (2007) The variation of nitrifying bacterial population sizes in a sequencing batch reactor (SBR) treating low, mid, high concentrated synthetic wastewater. J Environ Eng Sci 6: 651-663

33. Gilderhus PA, Marking LL (1987) Comparative efficacy of 16 anesthetic chemicals on rainbow trout. N Am J Fish Manag 7:288 292

34. Soivio A, Nyholm K, Huhti M (1977) Effects of anaesthesia with MS 222, neutralized MS 222 and benzocaine on the blood constituents of rainbow trout, Salmo gairdneri. J Fish Biol 10:91-101

35. Demers NE, Bayne CJ (1997) The immediate effects of stress on hormones and plasma lysozyme in rainbow trout. Dev Comp Immunol 21:363-373

36. Nonaka M, Iwaki M, Nakai C, Nozaki M, Kaidoh T, NatsuumeSakai S, Takahashi M (1984) Purification of a major serum protein of rainbow trout (Salmo gairdneri) homologous to the third component of mammalian complement. J Biol Chem 259:6327-6333

37. Secombes CJ (1990) Isolation of salmonid macrophages and analysis of their killing activity. Tech Fish Immun 1:137-154

38. Budiño B, Cal RM, Piazzon MC, Lamas J (2006) The activity of several components of the innate immune system in diploid and triploid turbot. Comp Biochem Phys A 145:108-113

39. Yano T (1992) Assay of hemolytic complement activity. SOS Publications, New Jerse

40. Siwicki A, Anderson D (1993) Total immunoglobulin assay. Tech Fish Immun 3:23-30

41. Pottinger T, Carrick T (1999) A comparison of plasma glucose and plasma cortisol as selection markers for high and low stressresponsiveness in female rainbow trout. Aquaculture 175:351-363 
42. Pickering A, Pottinger T, Sumpter J (1987) On the use of dexamethasone to block the pituitary-interrenal axis in the brown trout, Salmo trutta L. Gen Comp Endocrin 65:346-353

43. Campbell T, Murru F (1990) An introduction to fish hematology. Compend Contin Educ Pract Vet 12:525-532

44. Grant KR (2015) Fish hematology and associated disorders. Vet Clin North Am Exot Anim Pract 18:83-103

45. Chen Y, Jin P, Cui Z, Xu T, Zhao R, Zheng Z (2019) Identification and characterization of Janthinobacterium svalbardensis F19, a novel low-C/N-tolerant denitrifying bacterium. Appl Sci 9:1937

46. Yang M, Lu D, Qin B, Liu Q, Zhao Y, Liu H, Ma J (2018) Highly efficient nitrogen removal of a coldness-resistant and low nutrient needed bacterium, Janthinobacterium sp. M-11. Bioresour Technol 256:366-373

47. Cho Y-J, Jung Y-J, Hong SG, Kim O-S (2017) Complete genome sequence of a psychrotolerant denitrifying bacterium, Janthinobacterium svalbardensis PAMC 27463. Genome Announ 5:e01178-e01117

48. Timmons MB, Ebeling JM (2010) Recirculating aquaculture. Cayuga Aqua Ventures Ithaca, USA

49. Svobodova Z, Machova J, Poleszczuk G, Hůda J, Hamáčková J, Kroupova H (2005) Nitrite poisoning of fish in aquaculture facilities with water-recirculating systems. Acta Vet Brno 74:129-137

50. Verstraete W, Alexander M (1972) Heterotrophic nitrification by Arthrobacter sp. J Bacteriol 110:955-961

51. Neilands J (1967) Hydroxamic acids in nature. Science 156:14431447

52. Conte F (2004) Stress and the welfare of cultured fish. App Anim Behav Sci 86:205-223

53. Yavuzcan Yildiz H, Robaina L, Pirhonen J, Mente E, Domínguez D, Parisi G (2017) Fish welfare in aquaponic systems: its relation to water quality with an emphasis on feed and faeces - a review. Water 9:13

54. Tort L (2011) Stress and immune modulation in fish. Dev Comp Immunol 35:1366-1375

55. Segner H, Sundh H, Buchmann K, Douxfils J, Sundell KS, Mathieu C, Ruane N, Jutfelt F, Toften H, Vaughan L (2012) Health of farmed fish: its relation to fish welfare and its utility as welfare indicator. Fish Physiol Biochem 38:85-105

56. Avnimelech Y (2009) Biofloc technology: a practical guide book. World Aquaculture Society

57. Martínez-Córdova LR, Emerenciano M, Miranda-Baeza A, Martínez-Porchas M (2015) Microbial-based systems for aquaculture of fish and shrimp: an updated review. Rev Aquac 7:131-148

58. Moss S (2002) Dietary importance of microbes and detritus in penaeid shrimp aquaculture. Microbial approaches to aquatic nutrition within environmentally sound aquaculture production systems: $1-18$

59. Gray AC (1981) Biological wastewater treatment: theory and applications. JSTOR

60. Chaturvedi P, Reddy G, Shivaji S (2005) Dyadobacter hamtensis sp. nov., from Hamta glacier, located in the Himalayas, India. Int J Syst Evol Microbiol 55:2113-2117

61. Allen MA (2014) Analysis of a bacterial nitrification Community in Lake Superior Enrichment Cultures. Bowling Green State University

62. Photphisutthiphong Y, Vatanyoopaisarn S (2019) Dyadobacter and Sphingobacterium isolated from herbivore manure in Thailand and their cellulolytic activity in various organic waste substrates. Agric Nat Resour 53:89-98-89-98
63. Suyal DC, Kumar S, Yadav A, Shouche Y, Goel R (2017) Cold stress and nitrogen deficiency affected protein expression of psychrotrophic Dyadobacter psychrophilus B2 and Pseudomonas jessenii MP1. Front Microbiol 8:430

64. Kim SJ, Shin SC, Hong SG, Lee YM, Lee H, Lee J, Choi I-G, Park H (2012) Genome sequence of Janthinobacterium sp. strain PAMC 25724 , isolated from alpine glacier cryoconite. Am Soc Microbiol

65. Shoemaker WR, Muscarella ME, Lennon JT (2015) Genome sequence of the soil bacterium Janthinobacterium sp. KBS0711. Genome Announc 3:e00689-e00615

66. Smith HJ, Foreman CM, Akiyama T, Franklin MJ, Devitt NP, Ramaraj T (2016) Genome sequence of Janthinobacterium sp. CG23_2, a Violacein-producing isolate from an Antarctic supraglacial stream. Genome Announc 4:e01468-e01415

67. Shivaji S, Ray M, Kumar GS, Reddy G, Saisree L, Wynn-Williams D (1991) Identification of Janthinobacterium lividum from the soils of the islands of scotia ridge and from Antarctic peninsula. Polar Biol 11:267-271

68. Asencio G, Lavin P, Alegría K, Domínguez M, Bello H, GonzálezRocha G, González-Aravena M (2014) Antibacterial activity of the Antarctic bacterium Janthinobacterium sp. SMN 33.6 against multiresistant Gram-negative bacteria. Electronic J Biotech 17(1):1-5

69. Brucker RM, Harris RN, Schwantes CR, Gallaher TN, Flaherty DC, Lam BA, Minbiole KPC (2008) Amphibian chemical defense: antifungal metabolites of the microsymbiont Janthinobacterium lividum on the salamander plethodon cinereus. J Chem Eco 34(11):1422-1429

70. Rebollar EA, Simonetti SJ, Shoemaker WR, Harris RN, Cullen D (2016) Direct and Indirect Horizontal Transmission of the Antifungal probiotic bacterium Janthinobacterium lividum on green frog (Lithobates clamitans) tadpoles. App Env Microbiol $82(8): 2457-2466$

71. Pidot SJ, Coyne S, Kloss F, Hertweck C (2014) Antibiotics from neglected bacterial sources. Int J Med Microbiol 304(1):14-22

72. Liang Z, Liu R, Zhao D, Wang L, Sun M, Wang M, Song L (2016) Ammonia exposure induces oxidative stress, endoplasmic reticulum stress and apoptosis in hepatopancreas of pacific white shrimp (Litopenaeus vannamei). Fish Shellfish Immunol 54:523-528

73. Randall DJ, Wright PA (1987) Ammonia distribution and excretion in fish. Fish Physiol Biochem 3(3):107-120

74. Ding Z, Kong Y, Zhang Y, Li J, Cao F, Zhou J, Ye J (2017) Effect of feeding frequency on growth, body composition, antioxidant status and mRNA expression of immunodependent genes before or after ammonia-N stress in juvenile oriental river prawn, Macrobrachium nipponense. Fish Shellfish Immun 68:428-434

75. Khansari AR, Balasch JC, Vallejos-Vidal E, Parra D, Reyes-López FE, Tort L (2018) Comparative immune- and stress-related transcript response induced by air exposure and Vibrio anguillarum bacterin in rainbow trout (Oncorhynchus mykiss) and gilthead seabream (Sparus aurata) mucosal surfaces. Front Immunol

76. Khansari AR, Parra D, Reyes-López FE, Tort L (2017) Modulatory in vitro effect of stress hormones on the cytokine response of rainbow trout and gilthead sea bream head kidney stimulated with Vibrio anguillarum bacterin. Fish Shellfish Immun 70:736-749

77. Janssen B (1996) Nitrogen mineralization in relation to C: $\mathrm{N}$ ratio and decomposability of organic materials progress in Nitrogen cycling studies. Springer, pp.69-75

78. Mengel K (1996) Turnover of organic nitrogen in soils and its availability to crops. Plant Soil 181 (1):83-93

79. Robertson GP, Groffman P (2007) Nitrogen transformations soil microbiology, ecology and biochemistry. Elsevier, pp.341-364 